\title{
Ibm Anak Asuh Lembaga Amil Zakat Baitul Muttaqien Dalam Menghadapi Dampak Negatif Telepon Seluler
}

\author{
Juli Ratnawati'), Yuniarsi Rahayu' ${ }^{2}$, Dwi Nurul Izzhati ${ }^{3)}$ \\ Jl. Nakula I No. 5-11 Semarang, 50131 \\ Telp. (024) 3517261, Faks. (024) 3569684 \\ E-mail:*1juli.ratnawati@dsn.dinus.ac.id, \\ 2yuniarsi.rahayu@dsn.dinus.ac.id, 3dwi.nurul.izzhati[@dsn.dinus.ac.id
}

\begin{abstract}
Abstrak
Perkembangan teknologi periode ini semakin meningkat dengan maraknya berbagai jenis inovasi khususnya teknologi telekomunikasi telepon seluler. Telepon seluler mampu meningkatkan produktivitas kerja bagi pemakainya akan tetapi juga dapat menimbulkan dampak negatif. Berbagai jenis kasus kejahatan berbasis telepon seluler antara lain penipuan, pornografi, bullying, prostitusi online, penculikan, penipuan, hate speech, hingga terorisme. Salah satu pemakai telepon seluler yang terbesar adalah remaja, sehingga mereka perlu dibekali dengan pengetahuan tentang pengaruh penggunaan telepon seluler. Lembaga Amil Zakat (LAZ) Baitul Muttaqien Universitas Dian Nuswantoro yang berdiri sejak tahun 2003 memiliki tujuan untuk memberdayakan anak-anak dari latar belakang tidak mampu di kota Semarang. Salah satu kegiatan yang dilakukan oleh LAZ adalah memberikan pelatihan pengembangan kapasitas melalui peningkatan manajemen diri dalam menghadapi dampak negatif perangkat telekomunikasi telepon seluler.
\end{abstract}

Kata kunci-telepon seluler, kapasitas, manajemen.

\begin{abstract}
Absract
The technological development of this period is increasing with the proliferation of various types of innovations, especially telecommunications technology, cellular telephones. Cellular phones can increase work productivity for users but can also have a negative impact. Various types of cell phonebased crime cases include fraud, pornography, bullying, online prostitution, kidnapping, fraud, hate speech, and terrorism. One of the biggest cell phone users is teenagers, so they need to be equipped with knowledge about the influence of cell phone use. The Baitul Muttaqien Amil Zakat Institution (LAZ) of Dian Nuswantoro University, which was established in 2003, aims to empower children from disadvantaged backgrounds in the city of Semarang. One of the activities carried out by LAZ was to provide capacity building training through improving self-management in the face of the negative impact of mobile telecommunication devices.
\end{abstract}

Keywords-smartphone, capacity, management.

\section{PENDAHULUAN}

Seiring dengan pertumbuhan teknologi saat ini maka berbagai jenis inovasi khususnya teknologi di bidang telekomunikasi telepon seluler semakin berkembang dengan maraknya berbagi fitur di dalamnya. Mampu meningkatkan produktivitas kerja, jarak yang jauh terasa semakin dekat dan terasa hadir di tengah - tengah kita, kegiatan bisnis, kegiatan sosial , kegiatan pendidikan semuanya dapat dipermudah dengan menggunakan telepon seluler (ponsel). 
Perkembangan suatu bangsa dapat dilihat dengan dengan meningkatnya penggunaan teknologi. Salah satu indikator penentu kemajuan bangsa yakni dengan kemudahan dalam mendapatkan teknologi telekomunikasi khususnya penggunaan telepon seluler. Menurut data di tahun 2017, pengguna telepon seluler di Indonesia jumlahnya mencapai 371,4 juta pemakai atau hamper mencapai 142 persen dari total keseluruhan populasi yakni 262 juta jiwa. Ini mengindikasikan bahwa setiap penduduk menggunakan 1,4 telepon seluler yang berarti satu orang menggunakan 2-3 kartu telepon seluler. Jumlah kaum urban di Indonesia hampir mencapai 55 persen dari total populasi [1]..

Kemajuan teknologi juga memiliki dampak negatif karena menyebarkan ketakutan serta keresahan dalam kehidupan manusia. Berbagai kasus kejahatan berbasis telepon seluler antara lain, pornografi penipuan, bullying, penculikan, penipuan, hate speech, prostitusi online, hingga terorisme. Semula kemajuan teknologi mampu mempermemudah usaha manusia, akan tetapi ketika urusan menjadi semakin mudah, akhirnya muncul rasa kesepian dan keterasingan sehingga rasa solidaritas, kebersamaan, dan silaturrahmi akan luntur [2]. .

Menurut Komisi Perlindungan Anak Indonesia (KPAI) berbagai jenis kasus berbasis siber (cyber crime) telah menduduki peringkat ketiga yakni sebanyak 414 kasus, yang akhirnya menggeser kasus lain yang berat yakni pelanggaran anak dalam pendidikan sebanyak 328 kasus [3]. Akhir-akhir ini di Indonesia selama terdapat kecenderungan permasalahan remaja yang serius di bidang sosial, psikologi, budaya, dan moralitas. Gambaran mengenai banyaknya remaja yang mengalami masalah sosial terlihat dalam bentuk perbuatan kriminal, asusila, serta pergaulan bebas sedangkan masalah budaya meliputi kehilangan identitas diri, terpengaruh budaya barat. Adapun masalah degradasi moral terlihat dalam bentuk kurang menghormati orang lain, tidak jujur bahkan terdapat usaha menyakiti diri seperti mengkonsumsi narkoba, mabukmabukan dan bunuh diri [4]. Oleh karena itu untuk menanggulangi halhal tersebut perlu manajemen diri.

Manajemen diri yang dimaksud disini merupakan totalitas dari segala pemikiran, keinginan serta gerakan yang dilakukan dalam ruang dan waktu sehingga dapat mendorong pengembangan kapasitas dalam ruang intelektual, emosional, spiritual dan fisik dalam membentuk generasi muda. Lembaga Amil Zakat (LAZ) Baitul Muttaqien UDINUS adalah lembaga yang berdiri pada tahun 2003 memiliki tujuan memberdayakan anak-anak dari kalangan tidak mampu di kota Semarang. Dalam menghadapi dampak negatif penggunaan telepon seluler maka LAZ Baitul Muttaqien Universitas Dian Nuswantoro memberikan penguatan moral berupa pengembangan kapasitas manajemen diri kepada anak asuhnya.

\subsection{Analisis Masalah}

\section{METODE PELAKSANAAN}

Anak asuh Lembaga Amil Zakat Baitul Muttaqien menghadapi masalah sebagai berikut:

1. Anak-anak binaan Lembaga Amil Zakat belum memahami memanajemen diri.

2. Anak-anak asuh Lembaga Amil Zakat Baitul Muttaqien belum memiliki kemampuan dalam mengendalikan pemakaian telepon seluler.

3. Anak-anak asuh Lembaga Amil Zakat Baitul Muttaqien perlu mengetahui konten aplikasi yang sesuai dengan usia mereka untuk mengantisipasi efek negatif penggunaan telepon seluler.

\subsection{Solusi Yang Ditawarkan}

Permasalahan yang dihadapi mitra diatas diatasi dengan memberikan pelatihan berupa pengembangan kapasitas untuk meningkaktan manajemen diri dalam upaya menghadapi efek negatif perangkat telekomunikasi telepon seluler.

Metode pelaksanaan kegiatan dilaksanakan dengan tahapan seperti bagan berikut : 


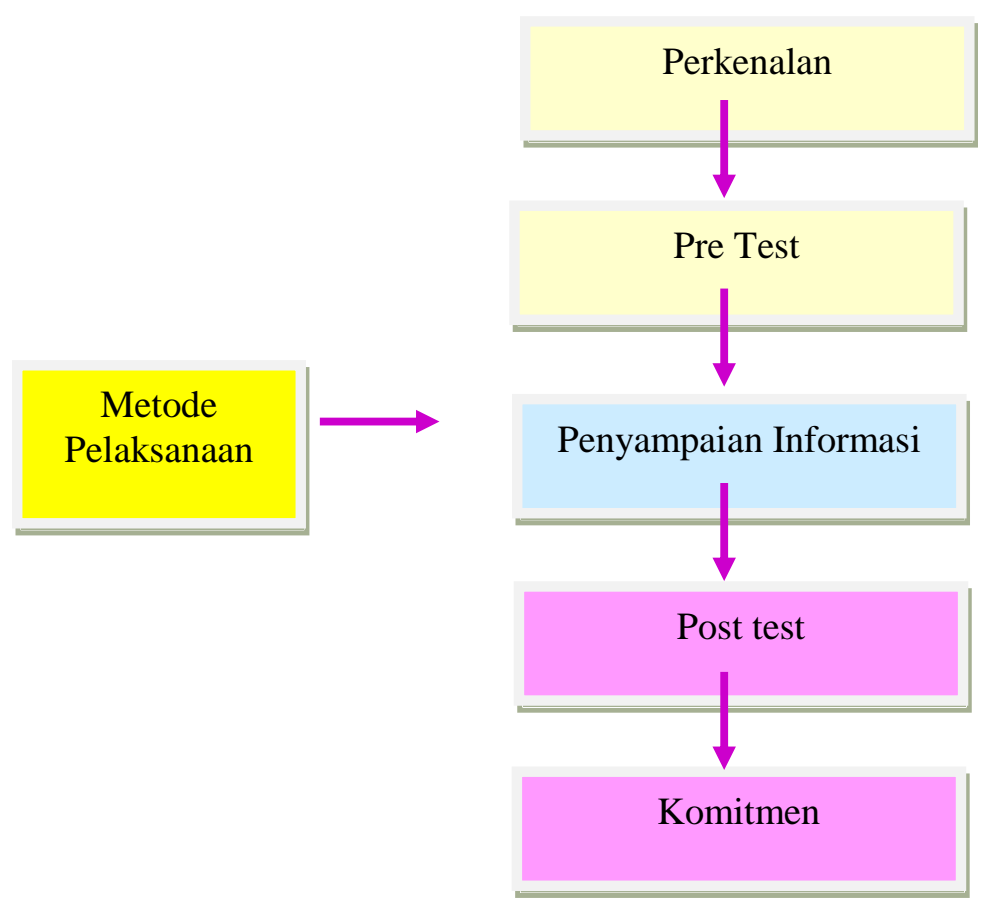

Gambar 1 Bagan tahapan pelaksanaan IbM

Keterangan tahapan pelaksanaan IbM pada gambar 1:

1. Perkenalan:

Dalam tahap ini tim pelaksana memperkenalkan diri kepada seluruh peserta pengabdian masyarakat.

2. Pre Test:

Pre test diberikan untuk mengetahui pengetahuan manajemen diri peserta dalam memakai seluler sebelum disampaikan informasi.

3. Penyampaian Informasi:

Media manajemen diri dipakai untuk menyampaikan informasi. Adapun informasi yang disampaikan berupa :

a. Kemampuan menyusun tujuan

b. Kemampuan menetapkan dan mengavaluasi kegiatan

c. Kemampuan penguatan diri (Emotional, Spiritual, Intelektual, Fisik)

4. Post Test

Post test dilakukan untuk mengetahui pengetahuan peserta akan pemakaian telepon seluler.

5. Komitmen

Komitmen dilakukan secara serentak dan bersama untuk menjadi yang baik, mandiri, cerdas, berakhlak luhur.

\section{HASIL DAN PEMBAHASAN}

Hasil dari pelaksanaan dari Pengabdian Masyarkat diatas adalah sebagai berikut:

Tabel 3.1 Capaian Pelaksanaan Pengabdian Masyarakat

\begin{tabular}{|l|l|l|l|}
\hline No & \multicolumn{1}{|c|}{ Tahap } & Output & Capaian \\
\hline 1 & $\begin{array}{l}\text { Persiapan } \\
\text { Menyiapkan materi pelatihan }\end{array}$ & Power point & $100 \%$ \\
\hline
\end{tabular}




\begin{tabular}{|l|l|l|l|}
\hline 2 & serta peralatan permainan & \\
\hline & $\begin{array}{l}\text { Pelaksanaan } \\
\text { Pelatihan diberikan kepada } \\
\text { peserta dengan memberikan } \\
\text { teori dan permainan secara } \\
\text { tim }\end{array}$ & $\begin{array}{l}\text { Peserta } \\
\text { mendapatkan } \\
\text { pengetahuan } \\
\text { tentang motivasi } \\
\text { diri, bahaya } \\
\text { telepon seluler } \\
\text { dan praktik } \\
\text { permainan } \\
\text { islami }\end{array}$ & \\
\hline 3 & $\begin{array}{l}\text { Pendampingan dilakukan } \\
\text { Pendampingan memberikan } \\
\text { dengan diadakan } \\
\text { mentoring yang dan } \\
\text { setiap Minggu di masjid } \\
\text { Baitul Muttaqien UDINUS. }\end{array}$ & $\begin{array}{l}\text { Peserta } \\
\text { memahami } \\
\text { bahaya } \\
\text { penggunaan } \\
\text { telepon seluler. }\end{array}$ & \\
\hline
\end{tabular}

\section{KESIMPULAN}

Pengabdian masyarakat ini dapat memberikan pengetahuan kepada anak-anak asuh Lembaga Amil Zakat Baitul Muttaqien mengenai bagaimana mengembangkan kemampuan kapasitas mereka dengan cara mengelola diri serta mengetahui fungsi, manfaat serta dampak negatif dari penggunaan telepon seluler.

\section{DAFTAR PUSTAKA}

[1] Https://databoks.katadata.co.id/datapublish/2017/08/29/pengguna-ponsel-indonesia-mencapai-142dari-populasi (Akses tanggal, 5 Oktober 2018)

[2] Ngafifi, Muhamad. 2014. Kemajuan teknologi dan Pola Hidup Manusia Dalam Perspektif Sosial Budaya. Jurnal Pembangunan Pendidikan: Fondasi dan Aplikasi. Volume 2, Nomor 1, Hal: 33-47.

[3] Https://www.validnews.id/Kejahatan-Siber-Dominasi-Kriminalitas-Tanah-Air-dGj (Akses tanggal, 5 Oktober 2018)

[4] Sriyanto, Aim Abdulkarim, Asmawi Zainul, Enok Maryani. 2014. Perilaku Asertif dan Kecenderungan Kenakalan Remaja Berdasarkan Pola Asuh dan Peran Media Massa. Jurnal Psikologi. Volume 41, Nomor 1, Hal: $74-88$. 